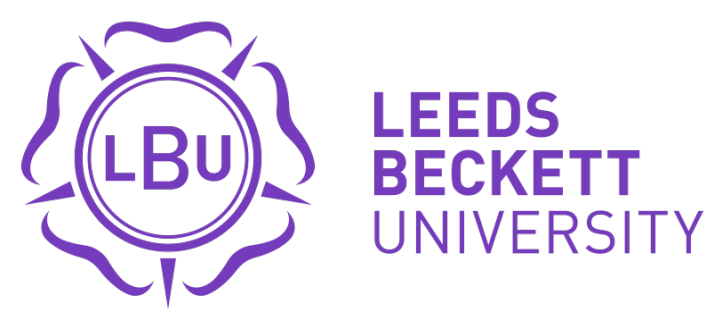

Citation:

Du Toit, $S$ and Withall, $A$ and O'Loughlin, $\mathrm{K}$ and Ninaus, $\mathrm{N}$ and Lovarini, $\mathrm{M}$ and Snoyman, $P$ and Butler, T and Forsyth, K and Surr, CA (2019) Best care options for older prisoners with dementia - a scoping review. International Psychogeriatrics. ISSN 1041-6102 DOI: https://doi.org/10.1017/S1041610219000681

Link to Leeds Beckett Repository record:

https://eprints.leedsbeckett.ac.uk/id/eprint/6016/

Document Version:

Article (Accepted Version)

The aim of the Leeds Beckett Repository is to provide open access to our research, as required by funder policies and permitted by publishers and copyright law.

The Leeds Beckett repository holds a wide range of publications, each of which has been checked for copyright and the relevant embargo period has been applied by the Research Services team.

We operate on a standard take-down policy. If you are the author or publisher of an output and you would like it removed from the repository, please contact us and we will investigate on a case-by-case basis.

Each thesis in the repository has been cleared where necessary by the author for third party copyright. If you would like a thesis to be removed from the repository or believe there is an issue with copyright, please contact us on openaccess@leedsbeckett.ac.uk and we will investigate on a case-by-case basis. 


\section{Best care options for older prisoners with dementia - a scoping review}

\section{Sanetta Henrietta Johanna Du Toit, ${ }^{1} \odot$ Adrienne Withall, ${ }^{2}$ Kate O'Loughlin, ${ }^{1}$} Nikola Ninaus, ${ }^{1}$ Meryl Lovarini, ${ }^{1}$ Phillip Snoyman, ${ }^{3}$ Tony Butler, ${ }^{4}$ Katrina Forsyth, ${ }^{5}$ and Claire A. Surr ${ }^{6}$

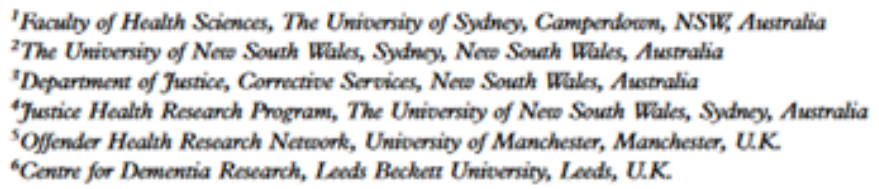

CT

\section{ABSTRACT}

Introduction: The prisoner population is ageing and consideration is needed for how to best support those with age-related health conditions in the system. Existing work practices and organisational structures often fail to meet the needs of prisoners with dementia, and prison staff experience high levels of burden due to these prisoners' increased needs. Little is known about the best method of responding to the needs of this growing sub-population of prisoners.

Method: A scoping review was conducted to answer the question: What are the perceived best care options for prisoners with dementia? To be included, publications had to be publicly available, reported on research findings, or viewed opinions and commentaries on care practices relevant to older prisoners with dementia. Searches were conducted in eleven databases to identify relevant publications. Data from the included publications were extracted and summarised into themes.

Results: Eight themes were identified that could support better care practices for prisoners with dementia: (1) early and ongoing screening for older prisoners; (2) specialised services; (3) specialised units; (4) programs/activities; (5) adaptations to current contexts; (6) early release or parole for older prisoners with dementia deemed at low risk of re-offending; and (7) training younger prisoners (8) as well as staff to assist 
Accepted for publication in International Psychogeriatrics 17 May 2019

older prisoners with dementia. Besides practical strategies improving care practice, costs, prison-specific resources and staff skills were highlighted as care barriers across all themes. A lack of empirical evidence supported these findings.

Conclusion: One of the implications of the international ageing prison population is higher numbers of people incarcerated with dementia. Suggestions for best care approaches for prisoners with dementia now need to move from opinion to empirical approaches to guide practice.

Key words: Dementia, care models, prisons, ageing, cognitive impairment, vulnerable populations 
Accepted for publication in International Psychogeriatrics 17 May 2019

\section{INTRODUCTION}

International trends indicate that ageing prisoners are one of the fastest growing groups within the prison population (Gaston, 2017; Norman, 2017). The United Kingdom (UK), for example, reported a $169 \%$ increase in the numbers of prisoners aged 50 and above over a 15-year period (Parliament House of Commons, 2017). Although there is no universal definition classifying prisoners as 'old' within the prison context, most definitions converge around 50 to 60 years (Cipriani et al., 2017; Lemieux et al., 2002; Yorston and Taylor, 2006; Prisons Department of Malaysia, 2013; Combalbert et al., 2018), except for Indigenous people in Australia where the threshold is 45 years (Baidawi et al., 2011). Despite variations in this definition, one of the key implications of an ageing prisoner population is the likely increase in the number of offenders with dementia. This includes recidivists with a lifetime of disadvantage and poor health, those who may offend due to their cognitive impairment, those who 'age in place' and develop dementia whilst in prison, and those incarcerated for the first time at an older age due to historical offences being prosecuted (Ginnivan et al., 2018).

Prisoners are not only acknowledged as a population prone to accelerated ageing processes, but poor health and life style choices, commencing prior to prison and maintained during imprisonment, are factors associated with the development of dementia for those who 'age in place' in the prison context (Kingston et al., 2011; Maschi et al., 2012). Currently a lack of research exists on older offenders with dementia (Combalbert et al., 2018; Curtice et al., 2003; Kakoullis et al., 2010) and no published data are available to confirm the prevalence of dementia among older prisoners. UK reports estimate levels around $5 \%$ of older adults in prison (Parliament House of Commons Justice Committee, 2013), while Forrest et al. (2017) suggest for Australia the number could be as high as $44 \%$ of the prisoner population. In the United States of America (USA), Williams, Stern et al. (2012) highlighted that a diagnosis of cognitive impairment was included in the medical records for $40 \%$ of prisoners 55 years and older; however, this includes a range of 
conditions other than dementia. Despite this lack of robust data it is likely that those with dementia make up an important segment of the prisoner population.

The care of prisoners with dementia is therefore an important emerging area of practice (Brooke et al., 2018). Currently dementia is not easily recognised in prison settings. On the one hand, highly regulated rules and routines may mask early signs of dementia. Behavioural disturbances associated with dementia such as agitation, aggression, and apathy/withdrawal can emerge due to an environment and practices that do not meet their needs. Given these behaviours are not uncommon generally in the prison context, the result may be punishment for breaking prison rules rather than being a trigger for assessment and provision for appropriate support (Cipriani et al., 2017; Gaston, 2017). Older frail prisoners are already vulnerable within the prison setting and their added diminished cognitive capacity makes them even more exposed to bullying, sexual assault and victimisation by other prisoners (Wilson and Barboza, 2010; Stojkovic, 2007).

Prisons were not originally designed for the purpose of providing health care or to support people with dementia, and there are numerous barriers for accessing the range of specialist health care and community services important for early dementia diagnosis and intervention. The ethical and legal implications of prisoners living with dementia without access to appropriate and specialised health care has been explored and deemed to be a violation of human rights, given the doubtful justification of punishment for someone who is deteriorating physically and mentally (Fazel, McMillan and O'Donnell, 2002). As the overall prisoner population continues to grow, prison services have increasingly limited resources to allocate permanent care of prisoners with dementia (Atabay, 2009).

Dementia care within population ageing is a priority area for continued research and practice development (Shah et al., 2016), but it is unclear how to best support the growing number of frail and vulnerable prisoners who are also impacted by this condition. Pham and 
colleagues (2014) suggest that scoping reviews are useful when a research area is new or has not been reviewed in-depth. A recent scoping review has explored the impact of dementia in the prison setting (Brooke et al., 2018), however possible ways to provide dedicated care for prisoners with dementia who age-in-place in the prison context have not been addressed. Brooke et al. (2018) identified challenges around identification of dementia in the prisoner population, difficulties in understanding and meeting the needs of older prisoners, and a lack of knowledge about dementia in prison staff and those working in the legal profession.

The aim of this scoping review is to present a synopsis of the existing literature relating to the provision of dementia care to prisoners, outlining existing and/or recommended models for best care practice for older prisoners with dementia.

\section{METHOD}

The extent, range and nature of peer-reviewed publications of care practices for prisoners with dementia were explored through a scoping review, based on the five steps specified by Arksey and O'Malley (2005). Given the emerging nature of this field, the quality of the studies was not evaluated, but Tricco et al.'s (2018) checklist for scoping reviews was adopted to enhance the methodological and reporting quality of this review.

\section{Step 1 - Identifying the research question}

The research question guiding the scoping review was, 'What are current best care options for prisoners with dementia?'

\section{Step 2 - Identifying the relevant studies}

The focus was on publications from 2000 until April 2018 that included full-text articles reporting empirical studies, or conceptual and theoretical perspectives. Due to the paucity of peer-reviewed publications, grey literature that reflected ongoing research, reported 
preliminary findings and trends in policy (e.g. reports and conference papers) and provided an understanding of care options for prisoners with dementia were also considered for inclusion (McKinstry, Brown and Gustafsson, 2014). Theses and books were excluded to promote a rapid review for establishing current evidence (Arksey and O'Malley, 2005). Only publications in English were considered.

The search included five categories broken down into synonyms (Figure 1). Studies were included if they involved the condition of dementia (first category) that impacted on prisoners (second category) who were considered old/older (third category) and were incarcerated (fourth category); and when reference was made to applicable services/support (fifth category). Publications were included where dementia was considered even if not the main focus of the publication.

\begin{tabular}{|c|c|c|c|c|}
\hline Concept 1 & Concept 2 & Concept 3 & Concept 4 & Concept 5 \\
\hline $\begin{array}{l}\text { - Alzheimer } \\
\text { Alzheimer } \\
\text { disease/ } \\
\text { cognitive defect) } \\
\text { - Dementia (senile } \\
\text { dementia/ pre- } \\
\text { senile dementia) } \\
\text { - Cognitive } \\
\text { Impairment } \\
\text { (cognition/ mild } \\
\text { cognitive } \\
\text { impairment)- } \\
\text { - Cognitive } \\
\text { Dysfunction } \\
\text { - Cognition } \\
\text { Disorders }\end{array}$ & $\begin{array}{l}\text { - Offender (\& } \\
\text { mentally ill } \\
\text { offender) } \\
\text { - Prisoner } \\
\text { - Criminal } \\
\text { - Inmate } \\
\text { - Felon }\end{array}$ & $\begin{array}{l}\text { - Elderly (frail } \\
\text { elderly/ elderly } \\
\text { care/ very } \\
\text { elderly) } \\
\text { - Old } \\
\text { - Older (Aged } 80 \\
\text { and over) } \\
\text { - Aged } \\
\text { - Aging (cognitive } \\
\text { aging) } \\
\text { - Ageing }\end{array}$ & $\begin{array}{l}\text { - Prison } \\
\text { - Gaol } \\
\text { - Jail (\& delivery of } \\
\text { health care) } \\
\text { - Incarceration } \\
\text { - Correctional } \\
\text { Facility (\& } \\
\text { correctional } \\
\text { health services) } \\
\text { - Imprison } \\
\text { - Custodial Facility } \\
\text { - Penitentiary }\end{array}$ & $\begin{array}{l}\text { - Care (elderly care/ } \\
\text { geriatric care) } \\
\text { - Service (mental } \\
\text { health services) } \\
\text { - Program } \\
\text { - Programme } \\
\text { - Facilities } \\
\text { - Support } \\
\text { - Rehab } \\
\text { - Rehabilitation } \\
\text { (rehabilitation care/ } \\
\text { cognitive } \\
\text { rehabilitation/ } \\
\text { geriatric } \\
\text { rehabilitation) } \\
\text { - Intervention } \\
\text { - Remediation } \\
\text { (cognitive } \\
\text { remediation } \\
\text { therapy/ cognitive } \\
\text { therapy) }\end{array}$ \\
\hline
\end{tabular}

Figure 1: Word strings for basic concepts used in searches

\section{Step 3 - Study selection}

Eleven bibliographic databases were searched and 3326 publications identified (see

Figure 2). These included Medline (77), Embase (91), Ageline (29), Cinahl (37), Cochrane 
library (37), Amed (2), Scopus (411), Web of Science (28), Proquest Health and Medical (830), Pubmed (36); Proquest Nursing and Allied Health (1274). After deleting duplicates (727), papers were then scanned by title and key words (see Figure 1) to ensure all five categories had been included. Exclusions were made, for example, when inmate referred to a person being resident in a non-prison setting (e.g. mental health institution) or the person was a 'prisoner of dementia'. Upon completing an initial title screening (2383), and removing publications prior to 2000 (135), the total number of publications for further review was 81.

Identified publications were downloaded into Endnote. One researcher conducted an initial screening of the titles of each document to ensure that irrelevant publications were removed. Two researchers independently screened the remainder of the publications by title and abstract to ensure that unsuitable publications were removed.

Finally, the full-text of the remaining publications were independently assessed against inclusion and exclusion criteria. Publications that referred to older prisoners with dementia once released from the prison setting were excluded. Literature/systematic reviews were excluded to ensure that published information was not duplicated, but their reference lists were utilised to check for additional papers of relevance. Only publications that made reference to the care of prisoners with dementia were included. In total 35 publications were included for final review. 
Figure 2: Publication selection process for review

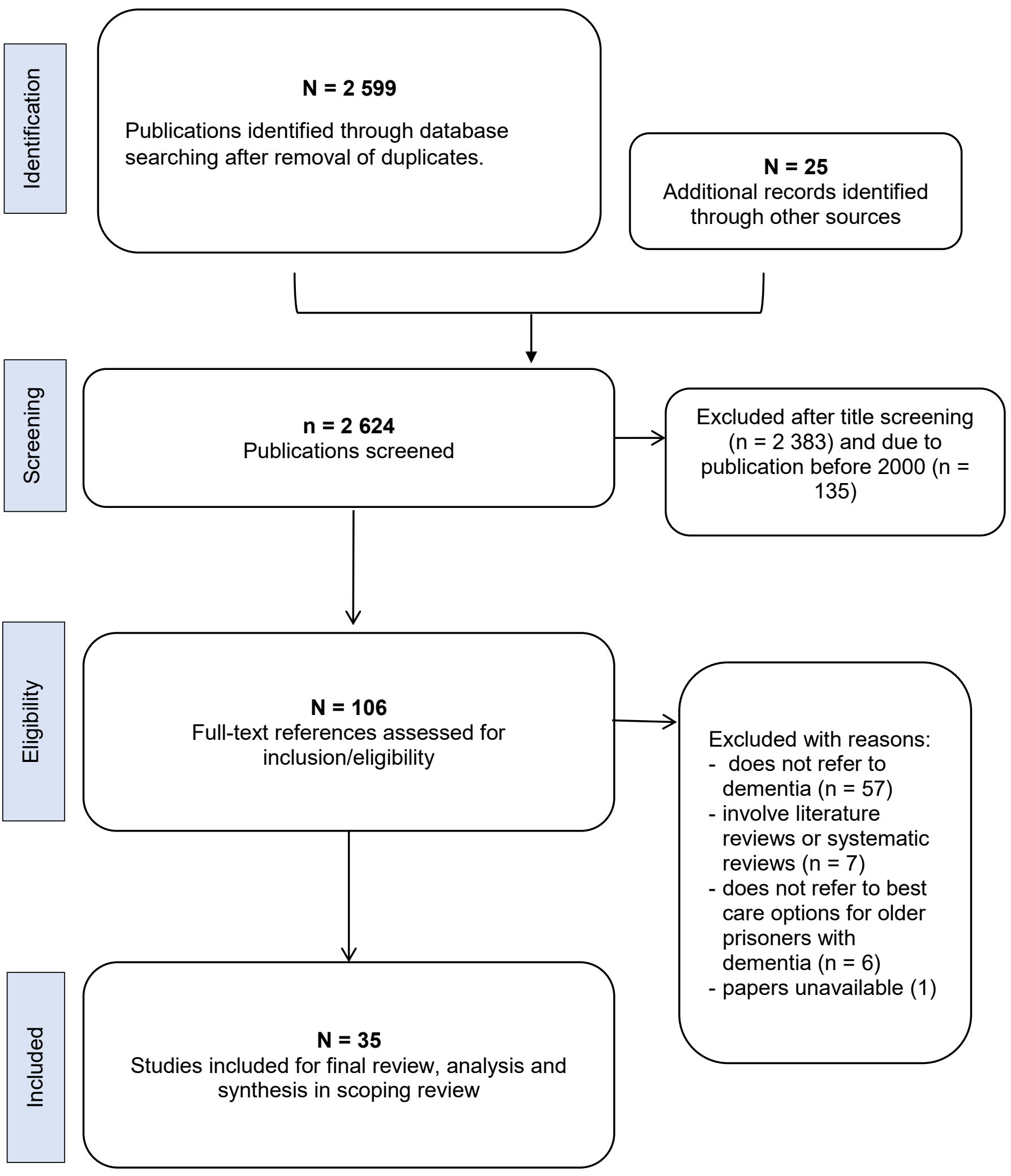




\section{Step 4 - Charting the data}

The full text of the 35 included publications were read and data extracted using a standard extraction form including details of the authors, year of publication, study location, type of publication (including study design), definition for 'older' prisoners, reasons for the growing number of older prisoners, and issues and challenges as well as suggestions/recommendations for the care of older prisoners with dementia (Table 1).

\section{Step 5 - Collating, summarising and reporting the results.}

The studies were summarised descriptively and findings compared to identify overlapping and opposing views that could support a better understanding of current literature on the care of prisoners with dementia.

\section{FINDINGS}

Findings are presented by providing an overview of included publications before discussing the eight themes that arose from the descriptive summary and collation of results.

\section{Characteristics of publications}

The 35 publications date from 2003 , with the majority written quite recently in the period between 2012 and 2018. In 2009 the United Nations included dementia when highlighting the special needs of offenders in prisons (Atabay, 2009). Many countries, including Malaysia, Switzerland, France, Italy and Canada, emphasised dementia in older offenders as problematic. Most publications retrieved were from the UK $(n=12)$, followed by Australia $(n=10)$ and then the USA $(n=7)$. If papers were classified under two countries, for example UK/Australia, both locations were counted.

The findings included only five research papers, of which four were qualitative and only one utilised a quantitative methodology. Most publications were discussion papers in 
scientific journals including conceptual frameworks and opinion pieces $(n=11)$ and commentaries in professional and conference publications $(n=11)$. Eight reports and position papers were also included that highlighted assumptions, hypotheses, and proposed principles for dementia care in prison (Table 1).

Insert Table 1 about here - Summary of included Publications and identified Themes

Overall the studies revealed a lack of services for older offenders, especially those with dementia. Some factors that were identified as impacting negatively on the health and wellbeing of prisoners living with dementia included the prison environment being particularly harsh for older offenders with dementia and other cognitive impairments (Maschi et al., 2012). Specific issues included over-crowding, noise, and the behaviour of other prisoners. It was also noted that a person's symptoms of dementia could either be exacerbated by this environment or masked by institutionalised routines (Beckett et al., 2003).

Eight themes were identified that could support better care practices for prisoners with dementia and other cognitive impairments (Table 1). These included early and ongoing cognitive screening for older offenders, training for correctional staff as well as health staff, provision of specialised services, specialised units or adaptations to the current environment, training younger prisoners to provide assistance, and early release or parole for those deemed at low risk of re-offending, or supervised release into specific hostel type accommodation.

\section{Early and ongoing cognitive screening and assessments}

Most publications (22; $62.9 \%)$ suggested that assessments to determine cognitive status should be conducted on a regular basis from a specific age. For example, on an annual basis when prisoners reach 50 years of age, and upon entry to prison for older offenders (Combalbert, 2002; Gaston 2017). This is especially needed as prisoners tend to 
underreport any cognitive or physical symptoms either for fear of repercussions, or due to poor insight into their cognitive impairment and deteriorating health (Combalbert et al., 2017). Screening could lead to the early identification of dementia and allow for supports to be put in place around treatment, accommodation and advanced care planning options (Gaston, 2017; Brown, 2014; Williams, Stern et al., 2012).

Factors that could negatively impact routine cognitive screening of older prisoners on admission include language barriers (Vogel et al., 2013) and/or being under the influence of drugs or alcohol (Patterson et al., 2014).

While there is consensus on the need for assessment, currently there is no uniform prisonspecific screening tool available (Patterson et al., 2016). The drawback of screening and assessment for a diagnosis of dementia is the cost associated with accessing specialised persons to conduct these evaluations.

\section{Specialised medical/health services for prisoners with dementia}

Interestingly, the majority of sources (29 publications) referred to a need for a specialised health care service for prisoners with dementia. These services could be defined as any dementia or cognitive-specific medical services (both in-reach and out-reach). One publication advocated for occupational therapy input in prisons to facilitate person-centred dementia care practices and promote meaningful engagement of older prisoners with dementia (Du Toit and McGrath, 2018).

Examples for referral processes to improve early diagnosis and promote early intervention included the Memory Services Prison Pathway from the UK (Moll, 2012b). Care pathways assist with monitoring and adjusting therapeutic pharmacological and non-pharmacological interventions as the disease progresses (Maschi et al., 2012). 
The biggest challenge to providing specialist geriatric care within prison settings is available resources and budgets (Beckett et al., 2003). An excellent care model for older prisoners, although not dementia-specific, is the protocol followed in the High Dependency Unit at Rimutaka Prison in New Zealand where all prisoners have their own health file, including an advance care directive and treatment plan (Brown, 2015). When a prisoner's health care needs change or if they require continuous support in the form of residential care, a Needs Assessment and Service Coordination (NASC) assessment is conducted as part of their regular care plan review (Brown, 2015).

\section{Specialised units within prisons}

Specialised or purpose-built units refer to facilities designed for older prisoners to live together away from the mainstream prisoner population. These prisoners may or may not have dementia, but adaptations are inclusive to support the needs of prisoners with dementia (Atabay, 2009).

Sixteen $(45.7 \%)$ publications included in the scoping review argued the pros and cons of specialised facilities. There is a range of examples of how specialised units accommodate older prisoners. Long Bay Hospital Aged Care and Rehabilitation Unit (Sydney, Australia), for example, has accessible corridors and doors, uses colour contrasts and has single cells with en-suites (NSW Justice, 2015). In Onomichi prison (Japan) there is a specialist unit that accommodates 61 older prisoners of whom more than half have some form of cognitive impairment, including dementia (Moll, 2012b). The unit was designed for less mobile prisoners, with customised wash areas, handrails and ramps instead of stairways, and with two full-time nurses on duty (Moll, 2012b). Separate wings for frail and/or prisoners needing protection from victimisation are also found in Merksplas (Antwerp, Belgium), Hocking Correctional Facility (Ohio, USA), Ouachita River Correctional Unit (Arkansas, USA), in Singen (Germany) and Laurel Highlands (Pennsylvania, USA) (Baldwin and Leete, 2012; Shilling, 2012). 
According to Atabay (2009: p. 135), 'taking into account resource limitations in most countries, there are strong arguments in favour of a system where the majority of older prisoners are placed in the general population, while only a small number who require specialist care and protection may be housed in special units". Maschi et al. (2012) argue that specialised units for older offenders are projected to be more expensive than mainstream housing. Furthermore, as specialised units in all prisons may not be financially viable, it could result in older prisoners being re-located (Atabay 2009). This will not only mean that prisoners with dementia may be moved away from their families, but will be placed in an unfamiliar environment which may exacerbate confusion.

\section{Special programs for prisoners}

Prison regimes target the needs of the majority, the younger prisoner population, and could easily exclude the needs of a minority group like older prisoners with dementia. Programs associated with health promotion for prisoners prone to cognitive decline include activities such as exercise, massage or participating in arts-based activities (Maschi et al., 2012). One third $(n=12)$ of publications referred to various work and recreation programs identified as special programs delivered or specifically adapted for older prisoners with dementia. These programs are run by prison authorities or, as a more cost-effective option, volunteer organisations are brought in to supervise and run the programs (Beckett et al., 2003).

Examples of innovative and cost-effective programs used in Japan and the USA are included in Table 2 (Maschi et al., 2012; Moll, 2012b). Dementia-specific programs include memory cafes that offer a range of activities like brain gym, gentle exercise, arts and crafts, creative writing, gardening, documentary screenings, yoga, tai chi, sing-alongs and easy games to play in prison yards (e.g. bowls, board games) (Moll, 2012b). Other activities offered include reminiscence and discussion groups about positive life events; meditation, 
reading, art and calligraphy clubs, karaoke sessions, visiting comedians or musicians, and simple games like dominoes, jigsaw puzzles or quizzes (Brown, 2015).

Beckett et al. (2003) highlight the advantages special programs as opportunities for socialisation, fellowship and recreation. Regrettably, in many countries, special programs for older prisoners, including those who live with dementia, are difficult to run and/or organise due to lack of funding. In NSW for example, staff shortages resulted in the removal of the role of activities officer which affected aged offenders disproportionately (NSW Justice, 2015).

Table 2: Examples of work and recreation programs for prisoners with dementia

\begin{tabular}{|l|l|l|l|}
\hline $\begin{array}{l}\text { Author/s \& } \\
\text { year }\end{array}$ & Country & Activities & Advantages \\
\hline Maschi et al. 2012 & $\begin{array}{l}\text { Nevada, USA } \\
\text { (Name of } \\
\text { program: } \\
\text { True Grit) }\end{array}$ & $\begin{array}{l}\text { Combination of: } \\
\text { - physical activity, } \\
\text { - therapy, } \\
\text { - arts }\end{array}$ & $\begin{array}{l}\text { Decreased doctor visits and } \\
\text { medications } \\
\text { Increased social support and well- } \\
\text { being }\end{array}$ \\
\hline Moll, 2012b & $\begin{array}{l}\text { Hiroshima, } \\
\text { Japan }\end{array}$ & $\begin{array}{l}\text { - threading beads } \\
\text { - or putting small products into } \\
\text { bags } \\
\text { - looking after turtles }\end{array}$ & $\begin{array}{l}\text { Cost effective to run } \\
\text { Encourage a sense of routine and } \\
\text { responsibility }\end{array}$ \\
& & & \\
\hline
\end{tabular}

\section{Adaptations within the current context}

Thirteen publications proposed that the most cost-effective way to cater for the needs of older prisoners with dementia is to adapt current environments to enable them to be managed locally, rather than being transferred to a specialised unit (Patterson et al., 2014) and moved away from local support systems.

Suggestions on how current contexts could be adapted include pragmatic approaches such as identifying sections of the prison that have wider corridors or where ramps are already in place (NSW Justice, 2015). Simple adaptations include the use of commodes, wheelchair ramps, walkers, handrails in showers, large lettering on signs and, where needed, mechanical lifts (Beckett et al., 2003). Maschi et al. (2012) also suggest the use of coloured walls to differentiate spaces (e.g. bathrooms), along with adaptions to support 
independence in everyday activities such as using velcro on clothing and issuing slip-on shoes. An increase in agitation, which could be perceived as prisoners experiencing cognitive impairment, could also be prevented by fitting older prisoners with hearing aids and eyeglasses to reduce strain and encourage orientation (Maschi et al., 2012).

Safety is a concern when older prisoners with dementia are living within the general prison population. There are different suggestions around managing prisoners with dementia who wander into a "wrong" or dangerous area, where they may panic or become hostile when confronted. Tagging systems are used for monitoring prisoners in Europe and dark strips and tiles in front of doorways are used to help prevent prisoners with dementia from crossing into these areas (Gross, 2007).

Triggers for behavioural disturbance should be identified and managed. High-glare lighting, uniform décor and high-level background noise can exacerbate confusion or increase agitation leading to violence (Gross, 2007). Simple interventions include providing a quiet, time-out place; putting up simple signs and visual cues or arrows for people who can no longer read; and identifying whether proximity to others, noise and activity levels are triggers for inappropriate behaviour (Gross, 2007).

Individual signage, such as using photos and the prisoner's name in large print to identify their cells could support orientation (Brown, 2015). Other suggestions include: painted sections in prison cells around toilets to distinguish the sleeping area from the bathroom area; painted pictures above sinks demonstrating how to wash hands; large calendars with pictures in the communal areas showing current day, date, month, year and holidays as well as routine events; and smaller calendars with pictorial information about weather and type of clothing appropriate for that day (Hodel and Sanchez, 2013). Other practical approaches to increase independence in eating include smaller tables in the dining hall with 
less noise and more time for eating (Hodel and Sanchez, 2013). Key to the successful implementation of these practical approaches is staff training.

An inspection of the context and how adaptations support older prisoners in Australia highlighted that even when cost effective policies and procedures are in place, other issues can negatively impact health and well-being (NSW Justice, 2015). Despite identifying positive aspects like ramps and the use of mobility aids, concern was raised about the lack of hygiene: 'with cockroach infestations and poor plumbing plainly visible' (NSW Justice, 2015: p. 9). Additionally, routines in certain prisons included that prisoners were 'locked outside during out-of-cell hours [where] there is often a lack of shelter from elements, which can be particularly harsh for aged inmates' (NSW Justice, 2015: p. 31), and the lack of supervision and access to other inmates or staff could lead to enhanced confusion for prisoners with dementia.

\section{Parole or early release to special accommodation}

The NSW Justice Report (2015) highlighted that despite adaptations, a range of issues exist that make the prison context highly detrimental for prisoners with dementia as they age. Increased falls risks alone are attributed to slippery and uneven floors, broken tiles, lack of handrails, cold and draughty cells, and cells too small to accommodate mobility aids (NSW Justice, 2015).

Release of frail older prisoners in need of constant care to community facilities such as a hospice, nursing home accommodation or assisted living facility in the community was recommended in 17 (48.6\%) publications (e.g. Maschi et al., 2012; Stojkovic, 2007). Support processes included law student volunteers assisting individual low-risk prisoners aged $55+$ years in obtaining pardons, parole or alternative forms of incarceration (Maschi et al., 2012). However, placement is problematic and can take a long time as residential care facilities are often reluctant to take prisoners (NSW Justice, 2015). 
Examples of how early release could be managed include: (1) Involving specialised external agencies such as the UK's RECOOP, a charity promoting care and resettlement of older offenders (Moll, 2012b); (2) Developing collaboration between state and privately-run organisations to meet the needs of the prison system (e.g. West Nursing Home, Connecticut, USA, Brown, 2015). The advantage of nursing home type facilities is that they operate with 24-hour skilled nursing care; provide assistance with daily living activities like bathing and dressing; have access to on-site physicians, provide secure dementia, hospice, palliative and mental health care; and have allied health support services such as occupational and speech therapy, social work, pastoral care, dietary services and recreational therapies (Brown, 2015). (3) Updating legislation to include house arrest for specific circumstances as in Uruguay that 'provides house arrest for offenders over 70 , with exception of those convicted of serious crimes such as homicide and rape' (Atabay, 2009: p.134).

Atabay (2009: p139) suggests that prison authorities should consider 'developing a different set of parole eligibility criteria relevant to the needs of long-term and older prisoners'. However, Baidawi et al. (2011) caution not merely contemplating safety implications for the community sector, but considering the impact on older prisoners of transitioning into unfamiliar environments and new routines, especially those who have been incarcerated for a long time.

\section{Staff training}

Dealing effectively with older prisoners with dementia relies on preparing staff. Training for custodial staff (correctional, parole, and probation officers) and clinicians who work with prisoners with dementia is recommended in 23 publications (65.7\%; e.g. Williams, Stern et al., 2012). Training program content (see Table 3) focuses on identifying issues for rapid and/or further referral and ways of managing dementia-associated behaviours. Maschi et 
al. (2012: p.448) stress the importance for staff to understand subjective experiences of prisoners with dementia and allowing them additional time for mental processing.

Table 3: Examples of dementia-related training programs for staff working with older prisoners

\begin{tabular}{|c|c|}
\hline Author/s \& year & Suggested training program content \\
\hline $\begin{array}{l}\text { Hodel and Sanchez } \\
(2013)\end{array}$ & $\begin{array}{l}\text { - Understanding causes and clinical presentation of dementia. } \\
\text { - Effective communication with people with dementia. } \\
\text { - Managing challenging behaviours (e.g. irritability). } \\
\text { - Identifying triggers for unwanted behaviour. }\end{array}$ \\
\hline $\begin{array}{l}\text { Williams Stern et al., } \\
2012\end{array}$ & $\begin{array}{l}\text { Equip staff to identify: } \\
\text { - possible age-associated conditions (e.g. vision loss and hearing deficits). } \\
\text { - possible age-associated physical conditions (e.g. falls and incontinence). } \\
\text { - possible age-related clinically diagnosed cognitive conditions (e.g. dementia } \\
\text { and delirium). } \\
\text { - prisoners who would benefit from rapid assessment by health care providers. } \\
\text { - ways to deal with the challenges that all such conditions can pose in the } \\
\text { custodial setting. }\end{array}$ \\
\hline
\end{tabular}

Cost effective ways to make training more accessible include video training packages (Dopson, 2005; Hodel and Sanchez, 2013), however there is no consensus on what should be recommended as baseline training or the time needed with proposed training courses ranging from 40 hours (Angus, 2015) to six months (Hodel and Sanchez, 2013).

The importance for custodial officers in daily contact with prisoners to identify issues in need of specialised medical input is highlighted (e.g. Vogel et al., 2013). In the UK 45,000 prison officers and other non-mental health staff underwent training to equip them with basic skills (Dopson, 2005), and the Council of Europe recommended training of prison staff of all ranks to better cater for the special problems of long-term prisoners (Atabay, 2009). However, Beckett et al. (2003) caution that basic training of custodial staff can never replace the skill-set of professional nurses.

\section{Prisoner training}

Various instances where fellow prisoners are trained to support older prisoners, including those with dementia, were mentioned in nine $(25.7 \%)$ of the reviewed publications. Not only 
does training provide younger prisoners with transferable skills that may assist with resettlement and crime desistance on release (Stewart and Lovely, 2017), but additional benefits include training that facilitates a sense of responsibility and is linked to diminished bullying of older prisoners, and payment for the services rendered (Maschi et al., 2012). To protect older, vulnerable prisoners, especially those living with dementia, these schemes are monitored closely to identify predatory behaviour exhibited by aides/buddies (Moll, 2012b). Selection processes (e.g. prisoners with good behaviour for at least 10 years; no history of cognitive or emotional problems) and prolonged training (up to 12 months) are suggested means to promote the protection of older prisoners (Hodel and Sanchez, 2013).

The benefits of trained buddies/aides for both the prison system and older prisoners with dementia are that they provide one-on-one care; is a high quality, lower cost alternative; facilitates greater levels of choice and provision of culturally responsive peer support; and could promote an increased sense of community between prisoners themselves, and between staff and prisoners (Stewart and Lovely, 2017).

\section{DISCUSSION}

This review confirmed the lack of research evidence into best care practice models for prisoners with dementia ageing-in-place. Of the five empirical studies included, two addressed screening for dementia and identified that older prisoners do not seek help when experiencing cognitive impairment (Combalbert et al., 2018) and that referrals for cognitive screening were mostly requested by solicitors (Curtice et al., 2003). Both studies estimated the prevalence of dementia amongst their research populations as approximately $20 \%$. A prison service evaluation (Stewart and Lovely, 2017) and an evaluation of policies (Patterson et al., 2016) both suggested the positive role of a buddy system or peer support for the older prisoner. Research by Williams (2012) highlighted the discrimination of older prisoners, including those with dementia, due to their inability to access social care services while in prison. 
A major outcome of this scoping review is discovering that attention is being given to care considerations for ageing prisoners with dementia, however very little of it is based on empirical research. Much of what has been written and published is in the form of commentaries or opinion pieces by health and care professionals and social justice advocates. Twenty-nine publications included in this review were opinion pieces or commentaries that stressed a lack of understanding of older prisoners in general, but especially the need to consider care options for older prisoners with dementia. However, there was little consensus on how best to address the situation within or across countries as often they referred to a very specific prison context.

A major barrier to providing appropriate care for this cohort is the lack of funding. Health costs of older offenders far outweigh that of younger offenders (Angus, 2015; Williams, Goodwin et al., 2012, Turner and Trotter, 2010; Potter et al., 2007; Shilling, 2012) due to multiple conditions and their complex care needs, and the expectation is that the cost to care for older prisoners with dementia would be even more. In a health policy context, providing optimal health care for prisoners may not be viewed as politically advantageous for governments and therefore is seldom addressed as a priority.

One option considered is early release from prison for the care of prisoners with dementia or those who become frail and more dependent on continuous care. This could be done either through parole (depending on time served), or early release for medical reasons such as terminal illness or frailty. However, this may not be appropriate as generally exprisoners are not viewed kindly in society, and therefore are unlikely to be accepted into mainstream hospices or residential care facilities (Baldwin and Leete, 2012). The public do not favour additional government funding on this population nor want to live near prisoners accommodated in specialised community facilities (Moll, 2012a). For example, older sex offenders are considered to have higher rates of dementia (Yarnell, Kirwin, and Zonana 
2017), but their crimes make it more difficult to get parole, they are a very marginalised group in prison, and community residential care facilities have no interest in accommodating them (Yarnell et al., 2017). While it may be helpful to release some prisoners with dementia, research is needed to assess what risk assessment protocols would need to be in place to support these processes.

Specialised custom-built units were mostly viewed as too costly (Beckett et al., 2003; Baldwin and Leete, 2012), however it was acknowledged they would protect older prisoners with dementia from victimisation, provide opportunities to develop specific programs (Atabay, 2009; Turner and Trotter, 2010), contribute to positive mental health (Atabay, 2009; Moll, 2012a), encourage a sense of identification with peers, stimulate social interaction (Atabay, 2009; Moll, 2012a), and assist in meeting nutritional and medical needs (Atabay, 2009; Christodoulou, 2012; Lemieux et al., 2002).

More cost-effective ways to address the needs of older prisoners with dementia included specialised activities to assist socialisation and self-expression (Moll, 2012b), or adaptations within the current environment similar to person-centred care approaches followed in residential care facilities (e.g. use of signage, adaptive equipment). Training of younger prisoners to assist with care could be mutually beneficial in providing new opportunities to develop social capital through education and meaningful activity, and in maintaining the dignity of the older prisoner being cared for (Stewart and Lovely, 2017). It is also one of the few options that could assist to offset the effects of institutionalisation and provide a means for person-centred care to older prisoners with dementia. Empirical evidence is needed on how one-on-one care, supported by on-going training, could equip the buddy/aide to support the growing needs of the prisoner with dementia.

The use of outside/volunteer agencies is rarely mentioned despite their potential role to provide cost-effective in-prison support for training, care services or running specialised 
programs. Future studies should explore the current role of outside agencies and how they could potentially support prisoners with dementia and decrease care demands on prison staff.

Barriers to the health and well-being of all older prisoners, including those who live with dementia and are ageing-in-place in the prison context, include a lack of stimulation, limited engagement in age-appropriate, meaningful activities, and poor diets (Maschi et al., 2012, UK Parliament House of Commons Justice Committee, 2013; Williams, Stern et al., 2012). Claims are made by allied health professions on how occupational therapy and dietetics could contribute to healthy ageing and management of conditions like dementia inside prison contexts (e.g. Brown, 2015; Du Toit and McGrath, 2018; Royal College of Occupational Therapy, 2018). An example is the provision of specific nutrition plans that are delivered to older offenders inside prison (Christodoulou, 2012: p.750) in an attempt to address the increased rate of cognitive decline due to a high intake of salt, carbohydrates and fat in conjunction with the sedentary prison lifestyle. These claims need to be substantiated by research evidence.

Additionally, the need for training of all corrective services staff to understand the complex care needs of all older prisoners was highlighted (Hayes et al., 2013; Sheffrin et al., 2016; Smee, 2013; Wahidin, 2005) and specialised services to support the care for this population suggested (Das et al., 2012; Fezco, 2014; Howse, 2002; Jeon et al., 2007; Kingston et al., 2011; Stojkovic, 2007; Yarnell et al., 2017). Although publications included in the review do consider major cognitive disorders like Alzheimer's disease as part of these complex conditions, there appears to be a lack of consideration of the full range of dementias. The fact that the term Alzheimer's disease rather than dementia was used in some publications either excludes consideration of other types of dementia or indicates a lack of understanding about dementia. Due to health inequalities in the older prisoner population there may well be a higher incidence of some less common types of dementia 
in a prison population due to alcohol and drug use, as well as potentially higher rates of vascular dementia due to poor coronary health. This implies that research into this topic in the prison population needs greater input from dementia specialists to develop accurate policy and guidelines based on contemporary research evidence in the field of aged dementia care.

There are limitations that need to be acknowledged with this review. The majority of papers included here were commentaries or opinion pieces and, while useful, the author(s) very often do not include any empirical evidence to support their claims. Findings from health and well-being projects implemented in prisons are not generally published. Some of the barriers encountered to promote research within prison contexts are the fact that most professionals working in prisons are practitioners, and that access for academics to do prisoner-related research is limited.

\section{CONCLUSION}

Older prisoners with dementia are increasing worldwide. Suggestions for best care approaches for prisoners with dementia now need to move from opinion to empirical approaches to guide practice. 
Disclosure statement: This study was supported by a University of Sydney Ageingin-place Seeding Grant.

\section{Conflict of interest declaration: None}

Description of authors' roles: All authors were involved in designing the study. SHJ du Toit, N Ninaus and CA Surr were involved in data collection and analysis. SHJ du Toit, K O'Loughlin, A Withall and CA Surr contributed to writing the paper. SHJ du Toit addressed all the reviewers comments.

\section{References:}

Please note: the star symbol $\left(^{*}\right)$ in front of references indicates the 35 papers included in the review.

*Angus, C. (2015). Older Prisoners: trends and challenges [e-brief 14/2015]. NSW Parliamentary Research Service.

Arksey, H. and O'Malley, L. (2005). Scoping studies: Towards a methodological framework. International Journal of Social Research Methodology, 8, 19-32.

*Atabay, T. (2009). Older Prisoners. In Handbook on prisoners with special needs (pp. 123-143). Criminal Justice Handbook Series, New York: United Nations.

*Baidawi, S., Turner, S., Trotter, C., Browning, C., Collier, P., O’Connor, D., and Sheehan, R. (2011). Older prisoners - A challenge for Australian corrections. Trends and Issues in Crime and Criminal Justice, No. 426.

*Baldwin, J., and Leete, J. (2012). Behind bars: the challenge of an ageing prison population, Australian Journal of Dementia Care, 1(2), 16-19.

*Beckett, J. R. N. B. G. N. C., Peternelj-Taylor, C. R. N. M., and Johnson, R. L. R. N. B. B. A. (2003). Growing old in the correctional system. Journal of Psychosocial Nursing \& Mental Health Services, 41(9), 12-18.

Brooke, J., Diaz-Gil, A., and Jackson, D. (2018). The impact of dementia in the prison setting: A systematic review. Dementia, 147130121880171.

doi:10.1177/1471301218801715

*Brown, J. (2014). Dementia in prison (Discussion paper no. 9, March), Alzheimer's Australia, retrieved from https://www.dementia.org.au/files/20140423-NSW-REPDementialnPrison.pdf.

*Brown, J. (2015, October). Living with Dementia in Prison, retrieved from https://www.churchilltrust.com.au/media/fellows/Brown_J_2015_Living_with_demen tia_in_prison.pdf. 
Christodoulou, M. (2012). Locked up and at risk of dementia. The Lancet Neurology, 11(9), 750-751.

Cipriani, G., Danti, S., Carlesi, C., and Di Fiorino, M. (2017). Old and dangerous: Prison and dementia. Journal of Forensic \& Legal Medicine, 51, 40-44. doi:https://dx.doi.org/10.1016/j.jflm.2017.07.004.

*Collins, D. R. and Bird, R. (2007). The Penitentiary visit - a new role for geriatricians? Age and Ageing, 36, 11-13. doi: 10.1093/ageing/afl144.

*Combalbert, N., Pennequin, V., Ferrand, C., Armand, M., Anselme, M., and Geffray, B. (2018). Cognitive impairment, self-perceived health and quality of life of older prisoners. Criminal Behaviour and Mental Health, 28(1), 36-49. doi:10.1002/cbm.2023.

*Correctional Service of Canada. (2013). Healthcare Considerations for Older Offenders. Newsletter of the Asian and Pacific Conference of Correctional Administrators, 34, 13-16.

*Cox, J. F., and Lawrence, J. E. (2010). Planning Services for Elderly Inmates With Mental Illness. Corrections Today, 72(3), 52-57.

*Curtice, M., Parker, J., Wismayer, F. S., and Tomison, A. (2003). The elderly offender: An 11-year survey of referrals to a regional forensic psychiatric service. Journal of Forensic Psychiatry and Psychology, 14(2), 253-265. doi:10.1080/1478994031000077989.

Das, K., Murray, K., Driscoll, R., and Nimmagadda, S. R. (2012). Assessment of healthcare and placement needs in an older forensic psychiatric population in comparison to a younger forensic psychiatric population. International Psychogeriatrics, 24(7), 1188-1190. doi:http://dx.doi.org/10.1017/S1041610212000130

*Dopson, L. (2005). No bars to better care. Nursing Older People, 17(1), 47-47.

*Duffin, C. (2010). Doing time: health care in the criminal justice system. Nursing Older People, 22(10), 14-18.

*Du Toit, S. H. J. and McGrath, M. (2017). Dementia in prisons: enabling better care for ageing prisoners. British Journal of Occupational Therapy, [Published online Dec 2017]. doi: $10.1177 / 0308022617744509$

Fazel, S., McMillan, J. and O'Donnell, I. (2002). Dementia in prison: ethical and legal implications. Journal of Medical Ethics, 28(3), 156-159.

Feczko, A. (2014). Dementia in the incarcerated elderly adult: innovative solutions to promote quality care. Journal of the American Association of Nurse Practitioners, 26(12), 640-648. doi:https://dx.doi.org/10.1002/2327-6924.12189

Fleming, R., and Sum, S. (2014). Empirical studies on the effectiveness of assistive technology in the care of people with dementia: a systematic review. Journal of Assistive Technologies, 8(1), 14-34. doi:http://dx.doi.org/10.1108/JAT-09-20120021.

Forrest, G., Baidawi, S, Atkinson, T., Small, H., Bernoth, M. (2017). Previously unrecognised issues: Managing the health of an ageing prison and homeless 
population. In: M. Bernoth and D. Winkler (2017). Healthy ageing and aged care. (pp. 221 - 231). Melbourne: Oxford University Press

*Gaston, S. (2017). Vulnerable prisoners: Dementia and the impact on prisoners, staff and the correctional setting. Collegian. doi:10.1016/j.colegn.2017.05.004.

Ginnivan, N. A., Butler, T. G., and Withall, A. N. (2018). The rising health, social and economic costs of Australia's ageing prisoner population. The Medical Journal of Australia, 209(10), 422-424.

*Gross, B. (2007). Elderly offenders: Implications for Corrections Personnel, Forensic Examiner, 16(1), 56-61.

Hayes, A. J., Burns, A., Turnbull, P., and Shaw, J. J. (2012). The health and social needs of older male prisoners. International Journal of Geriatric Psychiatry, 27(11), 1155-1162. doi:https://dx.doi.org/10.1002/gps.3761

*Hodel, B., and Sánchez, H. G. (2013). The Special Needs Program for Inmate-Patients with Dementia (SNPID): A psychosocial program provided in the prison system. Dementia, 12(5), 654-660. doi:10.1177/1471301211432952.

Howse, K. (2003). Growing Old in Prison: A scoping study on older prisoners. United Kingdom: Centre for Policy on Ageing and Prison Reform Trust.

Jeon, Y. H., Potter, E., Cashin, A., and Chenoweth, L. (2007). An Innovative Model of an Aged Care Hostel in the Prison Setting: process of benchmarking and evaluation. Geriaction, 25(3), 12-17.

Kakoullis, A., Le Mesurier, N., and Kingston, P. (2010). The mental health of older prisoners. International Psychogeriatrics, 22(5), 693-701. doi:http://dx.doi.org/10.1017/S1041610210000359.

Kingston, P., Le Mesurier, N., Yorston, G., Wardle, S., and Heath, L. (2011). Psychiatric morbidity in older prisoners: unrecognized and undertreated. International Psychogeriatrics, 23(8), 1354-1360. doi:https://dx.doi.org/10.1017/S1041610211000378.

Lemieux, C. M., Dyeson, T. B. and Castiglione, B. (2002). Revisiting the literature on prisoners who are older: are we wiser? The Prison Journal, 82(4), 440-458. doi: 10.1177/0032885502238680.

*Maschi, T. P. L. A., Kwak, J. P. M. S. W., Ko, E. P. L., and Morrissey, M. B. P. M. P. H. J. D. (2012). Forget Me Not: Dementia Prison. The Gerontologist, 52(4), 441.

McKinstry, C., Brown, T. and Gustafsson, L. (2014). Scoping reviews in occupational therapy: The what, why, and how to. Australian Occupational Therapy Journal, 61(2), 58-66.

Moll, A. (2013a). Losing track of time: Dementia and the ageing prison population: treatment of challenges and examples of good practice, London: Mental Health Foundation.

*Moll, A. (2013b). Dementia behind bars: an unexpected yet predictable crisis. Mental Health Today, 24-27. 
*Munday, D., Leaman, J., and O'Moore, E. (2017). Health and social care needs assessments of the older prison population - a guidance document, United Kingdom: Public Health England.

*Norman, A. (2017). Prison - no place for older people. Nursing Standard, 31(49), 29. doi:http://dx.doi.org/10.7748/ns.31.49.29.s24.

*NSW Justice, Inspector of Custodial Services. (2015). Old and Inside: Managing aged offenders in custody, retrieved from http://www.custodialinspector.justice.nsw.gov.au/Documents/Old\%20and\%20inside \%20Managing\%20aged\%20offenders\%20in\%20custody.pdf.

Parliament House of Commons. (2017). UK Prison Population Statistics Number SN/SG/04334, 20 April 2017. London: The Stationery Office

Parliament House of Commons Justice Committee. (2013). Older prisoners Fifth Report of 2013-2014 HC 89 [Incorporating HC 1100 i-iii] London: The Stationery Office

*Patterson, K., Newman, C., and Doona, K. (2016). Improving the care of older persons in Australian prisons using the Policy Delphi method. Dementia, 15(5), 1219-1233. doi:https://dx.doi.org/10.1177/1471301214557531

*Peate, I. (2013). Dementia care and offender populations. British Journal of Community Nursing, 18(6), 284-285.

Pham, M. T., Rajic, A., Grieg, J. D., Sargeant, J. M., Papadopoulos, A. and McEwan, S. A. (2014). A scoping review of scoping reviews: Advancing the approach and enhancing the consistency. Research Synthesis Methods, 5, 371-385. doi:10.1002/jrsm.1123.

*Potter, E., Cashin, A., Chenoweth, L., and Jeon, Y-H. (2007). The healthcare of older inmates in the correctional setting, International Journal of Prisoner Health, 3(3), 204-213.

*Prisons Department of Malaysia. (2013). Elderly Offenders in Malaysian Prisons. Newsletter of the Asian and Pacific Conference of Correctional Administrators, 34, 7-12.

Royal College of Occupational Therapy (2018). Prisons: The value of occupational therapy. Accessed at: http://cotimprovinglives.com/prisons-the-value-ofoccupational-therapy/

Shah, H., et al. (2016). Research priorities to reduce the global burden of dementia by 2025. The Lancet Neurology, 15, 1285-1294.

Sheffrin, M., Ahalt, C., Cenzer, I. S., and Williams, B. (2016). Geriatrics in jail: Educating professionals to improve the care of older inmates. Journal of General Internal Medicine, 1, S232.

*Shilling, D. (2012). Senior Citizens in Prison. Victimization of the Elderly \& Disabled, 15(2), 17-28.

Smee, K. (2013). Caring for the Ageing Prisoner, A New Age Issue. Newsletter of the Asian and Pacific Conference of Correctional Administrators, 34, 4-6.

Stanback, B. (2008). Mental illness in older offenders. The Gerontologist, 48, 132. 
*Stewart, W., and Lovely, R. (2017). Peer social support training in UK prisons. Nursing Standard, 32(7), 39. doi:http://dx.doi.org/10.7748/ns.2017.e10572

Stojkovic, S. (2007). Elderly prisoners: a growing and forgotten group within correctional systems vulnerable to elder abuse. Journal of Elder Abuse and Neglect, 19(3-4), 97-117.

Tricco, A. C., et al. (2018). PRISMA Extension for Scoping Reviews (PRISMA-ScR): Checklist and Explanation. Annals of Internal Medicine, 169, 467-473. doi: 10.7326/M18-0850.

Turner, S. and Trotter, C. (2010). Growing old in prison? A review of national and international research on Ageing Offenders. Corrections Research Paper Series No. 3, July. Victoria: Department of Justice.

*Vogel, T., Lanquillon, S., and Graf, M. (2013). When and why should mentally ill prisoners be transferred to secure hospitals: a proposed algorithm. International Journal of Law \& Psychiatry, 36(3-4), 281-286. doi:https://dx.doi.org/10.1016/j.ijlp.2013.04.021.

Wahidin, A. (2005). 'We are a significant minority': Old Women in English Prisons. British Society of Criminology online journal.

*Wheldon, A., and Williams, R. (2012). Development of a geriatrician led outreach service for older prisoners. Age and Ageing, 2, ii14. doi:http://dx.doi.org/10.1093/ageing/afs112.

*Williams, B. A., Goodwin, J. S., Baillargeon, J., Ahalt, C., and Walter, L. C. (2012). Addressing the Aging Crisis in U.S. Criminal Justice Health Care, Journal of American Geriatric Society, 60(6), 1150-1156, doi:10.1111/j.15325415.2012.03962.x.

*Williams, B. A., Stern, M. F., Mellow, J., Safer, M., and Greifinger, R. B. (2012). Aging in correctional custody: setting a policy agenda for older prisoner health care. American Journal of Public Health, 102(8), 1475-1481. doi:https://dx.doi.org/10.2105/AJPH.2012.300704.

*Williams, J. (2012). Social care an older prisoners, Journal of Social Work, 13(5), 471491.

Wilson J and Barboza S. (2010) The looming challenge of dementia in prisons. Correct Care 24 (2): 10-32.

Yarnell, S. C., Kirwin, P. D., and Zonana, H. V. (2017). Geriatrics and the Legal System. Journal of the American Academy of Psychiatry and the Law, 45(2), 208-217.

Yee, P., and Williams, B. (2013). Long term care behind bars: An aging population doing hard time. Journal of the American Geriatrics Society, 1, S168. doi:http://dx.doi.org/10.1111/jgs.12263

*Yorston, G. A., and Taylor, P. J. (2006). Commentary: Older offenders - No place to go? Journal of the American Academy of Psychiatry and the Law, 34(3), 333-337. 